\title{
THE MAKHAEVISTS AND THE RUSSIAN REVOLUTIONARY MOVEMENT
}

By the early years of the twentieth century, the two major socialist parties in Russia, the Social Democrats and the Socialist-Revolutionaries, had taken shape. But these two parties did not win the adherence of all of Russia's revolutionary activists. There existed in addition a series of small extremist groups that formed what might be called the "militant fringe" of the revolutionary movement. These groups differed among themselves on programs, methods and ultimate objectives, but they all rejected the leading parties as insufficiently committed to revolution or too slow-moving in their tactics to achieve it. Although they never attained the numerical or organizational strength of the SD's and SR's, they remained a significant element in the revolutionary movement and left their mark on Russia's political life. The three main components of the militant fringe were the anarchists, the SR Maximalists, and the Makhaevists. Of these the Makhaevists are almost unknown today, although they formed organizations in several cities and rivalled the Maximalists and anarchists for the allegiance of the revolutionary extremists. An account of their program and activities will help to shed light on a segment of the Russian political spectrum whose insight into Russia's social and political condition has been underestimated, and on the revolutionary role of its smallest but in many ways most original element.

The "Makhaevists" were adherents of Jan Waclaw Machajski, a Polish-born revolutionary and critic of socialism. (In Russia Machajski's name was sometimes corrupted into Makhaev. Hence his doctrines became known as "makhaevshchina" and his followers as "makhaevtsy", and the terms continued to be used.) He was born in Russian Poland in 1866 and began his political career as a student activist at Warsaw 
University, becoming a Marxist shortly before his arrest in 1892 . $^{1}$ He was imprisoned for three years by the Russian authorities and then exiled to Viliuisk in Eastern Siberia. There he undertook a re-examination of his position which resulted in his rejecting Marxism and formulating the doctrines that constitute Makhaevism. At the heart of those doctrines lay a prefiguration of the now familiar theory of the "new class". Machajski stressed the growing importance of the managers, technicians, and white-collar workers of industrial society - the "intellectual workers", or intelligentsia (Machajski used the two terms interchangeably), those who made their living by mental rather than manual work. This "new middle class", generated by the development of capitalism and owing its position not to its ownership of property but to its education and monopoly on technical expertise, was gradually displacing the capitalists as the ruling class of modern society. For this reason, Machajski believed, it was a greater enemy of the proletariat than were the landlords and factory-owners.

The most novel aspect of his doctrines was the connection he drew between this rising new class and socialism: socialism was the ideology of the intellectual workers, and the socialists served as the spokesmen for their interests. Through their leadership of the labor movement, the socialists hoped to use the workers to exert pressure on the established authorities. But they did not want a fundamental economic transformation of capitalist society, a "proletarian" revolution that would achieve real equality, for that would abolish the privileges of the intellectual workers along with those of the capitalists. Their objective was political democratization rather than social and economic upheaval, an objective which, in Russia, was expressed in the drive for a "bourgeois" revolution. The socialists wished not to destroy capitalism but ultimately to take it over intact and run it themselves, having come to power by parliamentary means. This was the real meaning of the socialist goal of "socialization of the means of production". In itself, social-

1 Several accounts of Machajski's life and thought are now available, and therefore only a summary of his main doctrines is given here. For further details see Max Nomad, Aspects of Revolt (New York, 1959), pp. 96-117; Paul Avrich, "What Is 'Makhaevism'?" in: Soviet Studies (July, 1965), pp. 66-75; Marshall Shatz, "Jan Waclaw Machajski: The 'Conspiracy' of the Intellectuals", in: Survey (Jan., 1967), pp. 45-57. The most extended treatment of Machajski's ideas, relating them primarily to his early formative experiences in Poland, is Anthony D'Agostino, "Intelligentsia Socialism and the 'Workers' Revolution': The Views of J. W. Machajski", in : International Review of Social History, XIV (1969), pp. 54-89. As the present paper is intended to show, although some aspects of Machajski's thought may have had their roots in the Polish situation, Makhaevism as a revolutionary movement developed in direct response to Russian social and political conditions. 
ization would have little relevance for the workers. Their economic position in the industrial system would remain virtually unchanged, while the profits of the system would now accrue to their bosses, the educated managers and specialists.

Since Machajski considered education and not ownership to be the fundamental source of class inequality, he believed that the goal of the labor movement must be what he called the "socialization of knowledge". True social and economic equality would be achieved only when every worker was in a position to educate his children in the same way as the intelligentsia. Only then would there cease to be a ruling class which owed its dominating position to its hereditary monopoly on education, and an exploited class condemned to manual labor by its ignorance. Once equality of education was achieved, presumably, the workers would be in a position to take control of production and introduce socialism without the risk of dependence on the intellectual workers. ${ }^{1}$

The foregoing, in the briefest terms, were the main social and historical doctrines of Makhaevism. The Makhaevist revolutionary program was the product of Machajski's efforts, and those of his followers, to apply those doctrines to Russian conditions of the early twentieth century. Central to Machajski's thinking, and a major source of inspiration for his revolutionary program, was his interpretation of the workers' insurrection of June, 1848, in Paris. He returned to this episode again and again in his writings, for he regarded it as the great watershed both in the history of relations between workers and intelligentsia and in the development of socialism. He took as the starting point for his treatment of the June insurrection Marx's The Class Struggles in France 1848-50. At the beginning of this work Marx listed the segments of the bourgeoisie that had made up the opposition to the rule of Louis Philippe and the "finance aristocracy": the industrial bourgeoisie, the petty bourgeoisie, the peasantry, and "the ideological representatives and spokesmen of the above classes, their

1 Machajski himself never spelled this out clearly. His widow maintained that he never denied the value of socialism, and that he regarded socialization of the means of production as a necessary but not a sufficient condition for emancipating the workers. Vera Machajska [née Roza Levin], "Machajski's Views", unpublished manuscript in Russian, Max Nomad Archive, formerly in New York City, now housed in the Internationaal Instituut voor Sociale Geschiedenis, Amsterdam. (For a Polish translation of this manuscript, see Wiera Machajska, "Życie i poglądy Wacława Machajskiego", in: Wiadomości (London), March 4, 1962 , p. 2.) I would like to express my gratitude to Mr Nomad for his generosity in making his archive available to me when it was in his possession, as well as for his encouragement and his reminiscences. 
savants, lawyers, doctors, etc., in a word: their so-called men of talent". ${ }^{1}$ Here, Machajski believed, Marx had illuminated a crucial point which his followers had ignored. The June Days provided irrefutable evidence that the "capitalist contradiction" was deeper than the Communist Manifesto had indicated, for it was not limited to the antagonism between capitalists and workers. The enemy of the proletariat was "not just the owners of capital, the monarchist plutocracy, the oppositional 'progressive' industrial bourgeoisie, but also the whole mass of privileged employees of the capitalist state: lawyers, journalists, scholars". ${ }^{2}$

Machajski saw the February revolution of 1848 as a family quarrel within the bourgeoisie, between the magnates in power under Louis Philippe, and the educated, who were seeking to improve their political and economic position. The latter won the support of the workers by convincing them that a democratic republic would help to resolve the proletariat's problems as well. Once the republic had been achieved, the bourgeoisie, in order to pacify the workers, created the national workshops to provide jobs for the unemployed. But then the Chamber of Deputies, elected by universal suffrage, voted to close the workshops on the grounds that it was not the responsibility of democracy to grant the workers a guaranteed wage and job security. It was on the experience of the June Days most of all that Machajski based his unshakable hostility to the principles of political democracy. This event had proved once and for all that "democracy, the democratic republic, is just a reinforced prison for the workers, and the struggle for universal freedom is a bourgeois deception." 3

Machajski assigned much of the blame for the suppression of the Paris workers to the intelligentsia, and particularly the socialists. The members of the national workshops "demanded only a very simple thing - security henceforth from starvation, from unemployment." 4 But the socialists were no more prepared to support this demand than the republicans, for their plans called for the realization of such goals only in the distant future, when a socialist order had been introduced. The workers' steadfast insistence on an immediate guarantee against starvation terrified not only the government and the liberals but even the hitherto revolutionary socialists. Therefore the

1 Karl Marx and Frederick Engels, Selected Works in Two Volumes (Moscow, 1955), I, p. 140.

2 A. Vol'skii [Jan Wacław Machajski], Umstvennyi rabochii (Geneva, 1904-05), Part I, p. 21; also ibid., pp. 70-71.

3 [Jan Wacław Machajski,] Burzhuaznaia revoliutsiia i rabochee delo (St Pet., 1906; first pub. Geneva, 1905), pp. 40-41.

4 Umstvennyi rabochii, Part III, sec. i, p. 10. 
"aristocracy of the mind" led the ranks of those who were determined to eliminate the refuge that the unemployed had found in the national workshops. "The suppressors were yesterday's conspirators, who had called the workers forth to struggle for 'the triumph of liberty'. 'Woe to June!' cried the revolutionary socialist intelligentsia, the students, along with Cavaignac."1

The June Days, Machajski felt, had completely transformed the attitude of the intelligentsia toward the workers. The specter of a spontaneous uprising of the workers with immediate, concrete demands now haurited even the most ardent socialists. The June insurrection was "the most portentous event of the whole century. Every politician, every 'revolutionary thinker' tries to keep silent about it, but inexorably it comes to his mind at every so-called spontaneous outburst of the working masses, with every mass disturbance in the proletariat."2 The task of the socialists now became the very delicate one of manipulating the labor movement in such a way as to further the intelligentsia's interests within the bourgeois order while at the same time holding back the workers from the total destruction of that order.

Marxism, Machajski maintained, became the leading socialist ideology in the second half of the century because it proved particularly well adapted to the intelligentsia's requirements. For Marxism taught that the full development of capitalism was the only road to socialism. By emphasizing this aspect of their doctrine, the Marxists could exploit the labor movement for their own political purposes while restraining the workers from a "premature" attack on the existing order. Thus revolutionary Marxism of the period 1848-50 evolved into Social Democracy, with its stress on the long-term political education of the workers, its use of legal, parliamentary tactics in the West and its pursuit of a "bourgeois revolution" in Russia. Machajski's effort to account for the concentration of contemporary Social Democracy on democratic objectives was what had led him originally to his discovery of the "new class", and throughout his career he continued to regard Marxism as the foremost expression of the interests of the intelligentsia.

\section{II}

Thus Machajski attached great significance to the June Days of 1848 as the first major clash between the intelligentsia and the proletariat.

I [Jan Wacław Machajski,] Bankrotstvo sotsializma XIX stoletiia (Geneva, 1905), p. 27. See Marx, The Class Struggles in France, Marx and Engels, Selected Works, I, p. 162.

${ }^{2}$ Umstvennyi rabochii, Part III, sec. i, p. 11. 
In his view the June insurrection marked the start of a spontaneous attack by the workers on the economic structure of capitalist society, and it had been betrayed by the intelligentsia, with the socialists in the vanguard. Machajski regarded the June episode as more than a historical lesson, however. He took it as a revolutionary model as well. His revolutionary program called for a Russian version of the June insurrection as the opening salvo of an inexorable attack on the social and economic foundations of Russia.

As the agents of that inexorable attack, Machajski looked to those social elements whose economic plight was as desperate as it had been among the "hungry workers" of Paris in 1848 . Thus he rejected tradeunions and the workers who belonged to them, regarding such organizations as a device, supported by both capitalists and socialists, to isolate the most wretched and therefore dangerous elements of the working class. Trade-unions encouraged peaceful methods of labor activity, not militant uprisings, and their efforts brought some results, for the bourgeoisie found it expedient to reward moderation. But the unions benefitted only the most skilled, steadily employed workers who found it easiest to organize, while they brought few gains to the poorest and most desperate segments of the working class, "those who have struck terror in the bourgeoisie". The net effect of the trade unions was to open "a deep breach between the better-paid workers and those who live in poverty". ${ }^{1}$ Machajski wrote off the "labor aristocracy" as a revolutionary force and concentrated his attention on those elements whose primary sentiment in regard to the existing order was resentment and rage.

Here, as in many other respects, Machajski showed himself to be one of the heirs of Michael Bakunin. Although he never acknowledged any indebtedness to Bakunin and rarely even mentioned him in his writings, his doctrines bore the unmistakable stamp of the master anarchist. Bakunin, too, had stressed the importance of educational differences as a source of class inequality $;^{2}$ and he had adumbrated the central concept of Makhaevism, the prospect of a "new class" of

1 A. Vol'skii, ed., Rabochii zagovor (Geneva), No 1, Sept.-Oct., 1907, pp. 69-74. Machajski himself wrote all the articles in this journal except the third. No further issues were published. On Machajski's rejection of what he considered the "pacified" strata of the working class, the members of trade unions and socialist organizations, see also his unpublished work, "An Unfinished Essay in the Nature of a Critique of Socialism", Slavonic Collection, New York Public Library, pp. 44-45. Machajski wrote this essay in 1910 or 1911. The manuscript (photocopy) is a Russian translation, made by Machajski's wife, of the Polish original.

2 Michel Bakounine, Oeuvres, ed. by Max Nettlau and James Guillaume (Paris, 1895-1913), V, p. 135. 
technologists and managers replacing the bourgeois property-owners as the rulers of the workers. ${ }^{1}$ But nowhere was the legacy of Bakuninism to Makhaevism more apparent than in regard to the social elements that were to provide the driving force of revolution. Here, too, Bakunin had led the way by placing his trust in the totally disinherited. Just after the defeat of France in 1870, he wrote that only a revolution could save the country and only the workers could carry it out, for, devoid of property, they would be prepared to complete the struggle even at the cost of seeing their cities destroyed and the land transformed into a desert. ${ }^{2}$ Elsewhere, more discriminatingly, he drew a distinction between the working class of the less developed countries, such as Italy, Spain, and the Slavic world, and that of the advanced countries of Western Europe. He looked to the former to begin the revolution, for the latter was already thoroughly imbued with bourgeois values and aspirations. Particularly in Italy he found "that wretched proletariat" which contained "all the wisdom and all the strength of the future social revolution". Only the fully dispossessed could generate the elemental force and the "positive passion for destruction" from which "new worlds" are born. ${ }^{3}$

In Russia, however, Bakunin sought this mentality among the peasantry. But unlike the populists he placed little faith in the village commune. Its patriarchal structure and its submission to outside authority, he felt, made it a conservative rather than a revolutionary force. Instead, he turned to the figure of the razboinik, the bandit of the Russian countryside, who stood outside even the mir. Banditry had served as a source of social rebellion in the past, for "the first rebels, the first revolutionaries in Russia, Pugachev and Sten'ka Razin, were bandits." Since the commune had become a tool of the government and the rich peasants, "banditry remains the only way out for the individual and for the whole people - a universal uprising, a revolution."4

For the same reasons as Bakunin, Machajski sought a popular force utterly devoid of attachment to existing institutions. But while Bakuninism was a pre-industrial ideology, at least in its application to Russia, Makhaevism appeared at a time when Russia was being deeply affected by the process of industrialization. Makhaevism was thoroughly urban, and it focused on the industrial towns of Russia, not the countryside. Therefore Machajski turned to the poorest and

1 M. A. Bakunin, Gosudarstvennost' i anarkhiia, A. I. Bakunin, ed., Polnoe sobranie sochinenii (St Pet., 1906), II, pp. 220-21.

Bakounine, Oeuvres, II, pp. 293-307.

Bakunin, Gosudarstvennost' i anarkhiia, pp. 49-50, 72.

- Ibid., pp. 256-58. For a stimulating discussion of the concept of the "social bandit" see E. J. Hobsbawm, Primitive Rebels (New York, 1965), chap. 2. 
most insecure elements of the urban population, the stepchildren of Russia's industrial revolution, in search of that "bandit" mentality which Bakunin had looked for in the countryside.

One group to which Machajski devoted considerable attention was the unemployed. He accused the Social Democrats of concerning themselves only with the "working proletariat", rejecting the unemployed as a Lumpenproletariat of sluggards and semi-criminals. ${ }^{1}$ But it was among the unemployed that the anger and resentment felt by the working class as a whole came to a boil.

"The unemployed man feels what he has sometimes forgotten while working. Amid the torments of hunger he feels that he was born a slave, born without any right to even the smallest share in the riches that surround him, created by generations of labor through the centuries, and augmented by the labor of his own life." 2

Here was a revolutionary force neglected by even the most radical of the socialists, for only a true revolutionary would go among the unemployed, "where the most intense dissatisfaction and despair exist", where "just one spark" would be enough to ignite an uprising. ${ }^{3}$

Machajski also turned his attention to the "dark elements" of the towns, those individuals whom an ordinary citizen might have regarded as hoodlums, part of the "mob", or at least disreputable characters. Thus he wrote approvingly of the Black Hundreds, the proto-fascist street gangs which appeared during the 1905 revolution. Machajski chose to regard them as representatives of the "hungry masses" reacting against a revolution which promised them meaningless political and civil rights instead of relief from their economic distress. A bourgeois revolution could give the masses nothing, while in the Black Hundreds they could at least plunder the fine shops. Machajski drew a parallel between the Black Hundreds and the Galician peasant uprising of 1846 . In Galicia, he wrote, the Polish nobility had demanded political rights from the Austrian government, and the Austrians had countered by instigating an uprising of the Galician peasants against their "freedom-loving masters". That the peasants were incited by a reactionary government did not alter the fact that they were venting their anger on their oppressors. Similarly, the Russian intelligentsia was struggling for "freedom" while the authorities were setting the Black Hundreds on it; but it was still true that "the Black Hundreds are

1 Umstvennyi rabochii, Part I, p. 36.

2 Burzhuaznaia revoliutsiia, p. 100.

3 Rabochii zagovor, p. 77. 
killing their masters who, not satisfied that they live by robbing the workers, are using the workers' struggle to intensify their parasitism." Social Democracy, with its pursuit of political objectives, could not help but alienate "the most poverty-stricken, the most wretched and hungry masses of Russia's working population". 1

It is not surprising that Machajski was accused of "sympathizing" with the Black Hundreds, ${ }^{2}$ but such a judgment requires considerable qualification. He probably had few qualms about their methods, for although he did not explicitly advocate violence it was implicit throughout his revolutionary program. ${ }^{3}$ But his ultimate objective was a social revolution, and he could therefore have little in common with the principles of the monarchist Black Hundreds. Furthermore, although he found it agreeable that intelligenty were being victimized, there is no evidence in his writings of the anti-semitism that marked the activities of the Black Hundreds. (Machajski's wife, in fact, was Jewish, as were some of his followers.) Therefore it can be said that Machajski "sympathized" with the Black Hundreds only to the extent that he regarded them as outcasts from "respectable" bourgeois society and hence imbued with elemental anti-establishment hostility. ${ }^{4}$

1 Burzhuaznaia revoliutsiia, pp. 72-74.

Ivanov-Razumnik, Ob intelligentsii (2nd ed., St Pet., 1910), pp. 86-88.

s Earlier in his career it had been explicit as well. When he was arrested in 1892 he was carrying copies of a manifesto, which he had written himself, to the striking workers of $k$ od $z$, urging them to oppose the troops sent against them with street barricades, bullets, and bombs. Feliks Perl [Res], Dzieje ruchu socjalistycznego w zaborze rosyjskim (Warsaw, 1958; first pub. 1910), pp. 420-21. 4 In a more romantic vein, Evgenii Lozinskii, the chief popularizer of Makhaevism, developed the image of the "hooligan". As Lozinskii pictured him, the hooligan was an unemployed vagrant whose home was the street and who lived by shady, if not actually criminal, means. He was the outsider par excellence, a man who owed nothing to society and was therefore free from its conventions and prejudices. Lozinskii regarded him as a fresh, healthy force whose mission was to purify Russian life by sweeping away its outworn "bourgeois" culture. "And there ... onto the historical stage has come the frenzied, dirty, outcast figure of the fighting 'hooligan'. Amid an ever growing chorus of timid or indignant 'oh's' and 'ah's' from all of educated society (including even the most revolutionary socialists), this 'hooligan' is beginning little by little to occupy the main arena of the historical struggle, not - oh, horrors! - as an enemy or rival to his 'employed', i.e., laboring comrades, but as an independent fighter against the whole exploiting world, who has decided to repay the latter savagely for his unnatural, wasted life." His arrival on the scene, Lozinskii wistfully suggested, "may be the beginning of the end of all our barbaric culture and civilization, all our hypocritical, cannibalistic progress." Gde vykhod? (St Pet., 1909), pp. 14-15. See also his Itogi i perspektivy rabochego dvizheniia (St Pet., 1909), pp. 350-53.

As always, Russia's writers were as sensitive to the social changes occurring around them as her revolutionaries, and the outcasts of urban life began to make their appearance in Russian literature in the early twentieth century. Probably 
The third and most important group that Machajski singled out as potential agents of revolution was the new industrial workers coming into the towns from the countryside, those peasants who were being forced off the land by deteriorating economic conditions and later by the Stolypin reforms, and were providing Russia's rapidly expanding industries with raw new labor recruits. Machajski had shown an interest in the semi-peasant laborer as early as his first published work, Umstvennyi rabochii (The Intellectual Worker), which he wrote in Siberia in 1898. Here he criticized the populists of the seventies for denying the existence of a proletariat in Russia; even at that time, he maintained, Russia had a significant number of "vagrant workers" [bosiaki-proletarii], "new millions" of whom were constantly being sent forth by the villages. ${ }^{1}$ Machajski had no sympathy for the peasants as long as they remained tillers of the soil, and he felt that their craving for more land bound them irrevocably to the bourgeois system of property-relationships. ${ }^{2}$ But he very much appreciated them when they left the village and came to town.

"The rural poor will take up their struggle and the struggle of all the hungry only when they abandon once and for all their hopes for a black repartition and detach themselves from those peasants who want to strengthen and extend peasant landholding. Then these starving paupers will join the universal workers' struggle not for land, not for stolen property, but for a human existence for the slaves whom age-old robbery has sentenced to the lifelong penal servitude of manual work. Then they will attack not only the landlords' property but that of the whole bourgeoisie. They will flock into the rich towns and together with the urban unemployed will demand security from famine and from unemployment. They will raise a revolt of the slaves like the one the workers of Paris raised half a century ago." 3

Machajski's insistence on tangible economic gains as the sole objective of the workers' movement was expressly calculated to appeal to this group.

the best-known work on this theme is Gorky's play The Lower Depths. Even more striking in this respect, however, is another play, Leonịd Andreev's Tsar Hunger (1907). With its description of the most downtrodden of the industrial workers joining forces with the city's criminal elements to raise a revolt of the hungry against the privileged classes - and their defeat by the forces of modern science - Andreev's play reads almost like a scenario for a Makhaevist revolution.

1 Umstvennyi rabochii, Part III, sec. i, p. 16.

- Burzhuaznaia revoliutsiia, pp. 48-49.

Ibid., pp. 49-50. 
"All strata of the working population rally in a moment to a mass economic strike, even the most benighted, the most uneducated. The cause is understandable to each one, even to the illiterate fellow who arrived just yesterday from the backwoods village, who has not heard any agitators nor known any socialist ideas. Even unorganized workers such as domestic servants, it turns out, unite at such a moment."1

What attracted Machajski to the new industrial workers was the extremist psychology they brought with them from the countryside. Arriving from the village ignorant and unskilled, the new worker had few defenses against the insecurities of industrial life at this stage of its development, and he was the primary victim of low wages and frequent unemployment. What labor organizations existed were of little assistance to him, for, as Machajski pointed out, they tended to be limited to the skilled and the steadily employed. It was not only the frustration engendered in such individuals that made them potential recruits to political extremism, but the means they could be expected to adopt in coping with it. If anyone stood outside the legal framework of Russian society, it was the peasant; for generations the helpless object of constituted authority vested in the nobility and the bureaucracy, his traditional recourse when his endurance was exhausted was "direct action", usually accompanied by violence. As Machajski was well aware, the proletarianized peasant, uprooted from the land and cast adrift in the new conditions of urban life and factory labor, lost even the vestiges of conservatism which attachment to his property had given him. The new industrial worker brought with him to the town his essentially anarchic approach to social and economic grievances. And it was to him particularly that Machajski looked for the spark that would touch off the general conflagration. ${ }^{2}$

1 Ibid., p. 77.

2 On the significance of this element in the urban labor force, and its outlook, see A. M. Pankratova, "Proletarizatsiia krest'ianstva $i$ ee rol' $v$ formirovanii promyshlennogo proletariata Rossii (60-90-e gody XIX v.)", in: Istoricheskie zapiski, No 54, 1955, pp. 194-220; Theodore Von Laue, "Russian Peasants in the Factory, 1892-1904", in: Journal of Economic History, March, 1961, pp. 61-80; Leopold Haimson, "The Problem of Social Stability in Urban Russia, 19051917', I, in: Slavic Review, December, 1964, pp. 619-42; Adam Ulam, The Unfinished Revolution (New York, 1960), chaps. 3, 4.

The interest of the Makhaevists in this element was recognized by the Soviet historian of the movement, L. Syrkin, who otherwise tried to minimize his subject's social relevance. Syrkin applied the usual Soviet interpretation of anarchism - that it appealed to the obsolescent victims of industrial progress - to Makhaevism, and labelled it the ideology of the "declassed petty bourgeoisie". He included in this category, however, not only "ruined artisans" but also the 


\section{III}

In the actual mechanics of revolution, the general strike occupied a prominent place in Machajski's thinking. In the course of his first revolutionary adventure in Russia, in Irkutsk in 1902, he outlined his plan in a May Day proclamation to the workers. He called for an "international conspiracy of the workers" which would organize a general strike on the first of May. The workers' sole demand would be immediate improvement of the conditions and rewards of labor. They would try to make their work stoppages as universal as possible, proceeding en masse from factory to factory until entire cities were affected. Machajski warned that the intelligentsia would brand such an uprising "the wild outbursts of rabble" and would try to restrain it. The workers must repudiate the socialists and their demand for political demonstrations and fight solely for their own economic cause. ${ }^{1}$

A year after Machajski composed his Irkutsk proclamation, the south Russian strike of 1903 broke out. This event made a deep impression on him, and he took it as a corroboration of his basic positions. He viewed the strike movement as a concerted effort by the workers to turn a general strike into a workers' insurrection - an effort thwarted by the socialists. The spontaneous development of the strike and its initial presentation of purely economic demands contradicted the socialists' stand that the aim of the revolution must be a constitution. "The great outburst of worker resentment ... caught the Social Democrats completely unprepared. The working masses organized the strike in defiance of everything the Russian socialists were telling them and were writing in their pamphlets and newspapers." 2 The socialists then proceeded to divide the hitherto united working class by introducing political demands, which were responsible for the ethnic discords and antagonisms that soon arose between the different strata of the workers. ${ }^{3}$

Despite the importance Machajski attached to the notion of the general strike, however, it was not the sole or even the chief device in his revolutionary program; it was merely the spark-plug that would set the engine of revolution in motion. For a general strike necessarily depended on the employed workers, who, at best, were of secondary interest to Machajski. Therefore the general strike figured in his program mainly as a way of touching off a wider social upheaval that would

new industrial workers fresh from the countryside, certainly a highly significant social force in the Russian context. L. Syrkin, Makhaevshchina (MoscowLeningrad, 1931), pp. 62-65.

1 Umstvennyi rabochii, Part I, pp. 84-88.

2 Burzhuaznaia revoliutsiia, p. 67.

3 Ibid., pp. 75-77; also Umstvennyi rabochii, Part III, sec. i, p. 4. 
arouse the more volatile elements of the population: the unemployed, the more backward strata of the urban work force, and the rural poor.

The events of 1905 crystallized Machajski's thinking, and in his writings of 1905-07 he spelled out his revolutionary program in its final form. The Makhaevist revolution, as he now pictured it, was to start as a resurrection of the 1903 general strike and end as a new Russian edition of the June Days of Paris. Machajski believed that the 1903 strike, thanks to its concentration on economic demands, had started to attract "all segments of the urban working population, even the most uneducated". Had it continued along its original path it would surely have drawn in "the starving millions of the countryside". ${ }^{1}$ To achieve this, a new general strike must take place, its principal demand being the establishment of public works for the unemployed. Such a demand would mobilize a hitherto neglected revolutionary resource: "Neither the June insurgents of ' 48 in Paris, who raised a revolt against the republic which condemned them to starvation, nor unemployed workers who rebelled later were lucky enough to have even one learned socialist or revolutionary in their midst." 2 In turn the establishment of public works in the towns, like the national workshops in 1848 , would reinforce the ranks of the urban unemployed with hordes of distressed laborers from the surrounding countryside. Had it followed his program, Machajski asserted, the 1903 strike would have taken the following form:

"[It] would have attracted all the unemployed, all the vagrants whom the socialists scorn, for in order to confirm and support the conquests of the employed workers it would have demanded bread for the hungry, security for them from unemployment. But as soon as such a workers' uprising had succeeded in forcing the authorities of the provinces and the capital to establish public works for the unemployed, then it would have found on its side all the hungry millions of the countryside, who would now at last see the possibility of living, rather than dying in dreams of a black repartition." 3

The ultimate objective of this movement was to be the attainment of economic equality for the workers which in turn would assure them of educational equality, the sine qua non of their liberation. The workers could give their children the same education as the intelligenty only if their income reached the same level. The workers would therefore strike

1 Rabochii zagovor, pp. 12-13.

2 Burzhuaznaia revoliutsiia, p. 97.

Ibid., pp. 77-78; also Rabochii zagovor, p. 26. 
for higher and higher wages until they had, in effect, "expropriated" the intelligentsia. "But then the children of the manual workers will have the same opportunity for education as the children of the "whitehanded'. Equality of education will perforce be instituted ... All will equally become educated people; there will be no one to condemn to the modern penal servitude of lifelong manual work, no one to rob."1 Thus the "socialization of knowledge" would take place and with it the elimination of the distinction between "mental" and manual workers.

Machajski's program contained a number of serious contradictions. Its basic inspiration was implacable hatred of the existing order - but in fact it could attain its stated goals only by preserving that order and even opposing any effort to overthrow it. Machajski repeatedly warned that the workers could not immediately take control of production themselves because they lacked the knowledge required. But a prolonged strike movement to force the equalization of incomes, and the educational revolution that was to follow, implied the retention of the present political and economic structure for an indeterminate length of time. On the surface, at least, Makhaevism proposed not the seizure of power by the proletariat but merely the exertion of irresistible pressure on the established authorities.

It would appear from Machajski's writings that when he repudiated Social Democracy he also repudiated the notion of a "dictatorship of the proletariat". In his first work, Part I of Umstvennyi rabochii, composed originally in 1898 , before he made his definitive break with Social Democracy, he defined the proletariat's objective as the establishment of a "revolutionary dictatorship, the organization of the seizure of political power". ${ }^{2}$ Several years later, however, in the Preface to the printed edition of Part I, he spoke only of "world-wide workers' conspiracies dictating the laws to the state by means of world-wide workers' strikes". Instead of taking political power into its own hands, the proletariat would confront the state with "concrete demands capable of immediate realization". ${ }^{3}$ This now became the declared objective of Makhaevism. And in fact, the program of mobilizing the unemployed in itself precluded any attempt to overthrow the government. Unlike the employed workers, the unemployed had no way of wresting concessions from individual factory-owners. As Machajski recognized, they

1 Rabochii zagovor, p. 63; also Burzhuaznaia revoliutsiia, p. 111.

2 Umstvennyi rabochii, Part I, p. 30.

3 Ibid., pp. viii, xxiv. Only once more did he mention a dictatorship, but in a very ambiguous context, for the same passage also advocates the policy of pressuring rather than seizing the government. Umstvennyi rabochii, Part II, p. 55 . 
would have to turn to the government with their demand for the establishment of public works. ${ }^{1}$

Contemporary critics of Makhaevism pointed out some of the difficulties this program might encounter. One observer noted that the Makhaevists assumed a remarkable degree of forbearance on the part of the ruling classes, who were evidently expected to yield more and more of their wealth to the workers while placidly continuing to run the economy and the state. Another suggested that if the bourgeoisie decided to resist, the workers would be saved only in the event of their own defeat. For if they won, they would either have to renounce the fruits of their victory and restore the old state of affairs, or socialize the means of production - a step which Machajski insisted would bring with it the sway of the intellectual workers. ${ }^{2}$

There was another, even more serious flaw in Machajski's program: the discrepancy between its declared objectives and the psychology of the social forces who were supposed to attain them. Machajski sought to arouse those groups and individuals whose frustration and resentment he expected to generate the most uncompromising attack on the existing order. But could the goal of "socialization of knowledge" hold much meaning for such people? The unskilled, illiterate rural proletarian or newly urbanized worker had more pressing needs and narrower horizons. To educate one's children to be intelligenty was more likely to be the ambition of the more secure worker whose social expectations were beginning to rise - that relatively comfortable worker whose enthusiasm for revolution Machajski deeply mistrusted. The social forces on which Machajski pinned his hopes were better suited to overthrow a regime in a massive outburst of destructive violence than to exert unrelenting but limited pressure on it.

Quite possibly, this is just what Machajski had in mind. Although he denounced all existing working-class organizations as tools of the intellectuals, he urged the formation of a new underground party

1 Rabochii zagovor, pp. 80-82. Evgenii Lozinskii declared that the form of government was a matter of indifference to the working class, and that in some cases the workers might find that absolutism defended them better against the bourgeoisie than did parliamentary government. E. L., "Sotsializm i egalitarizm", in: Protiv techeniia (St Pet.), No 3, May 8, 1907, p. 11; Evgenii Lozinskii, Itogi parlamentarizma (St Pet., 1907), pp. 56-57.

${ }^{2}$ B. I. Gorev, "Apoliticheskie i antiparlamentskie gruppy", in: L. Martov et al., ed., Obshchestvennoe dvizhenie v Rossii v nachale XX-go veka (St Pet., 190914), III, p. 530; M. R[aev]skii, in: Burevestnik (Paris), March-April, 1908, pp. 31-32. Lest Machajski be thought uniquely lacking in political wisdom, it should be recalled that in 1917 some of the most sophisticated socialists in Russia attempted to apply a policy very similar to his in relation to the Provisional Government. 
which he termed the "workers' conspiracy". It would coordinate the proletariat's spontaneous outbursts into a regular, planned mass movement that would present the workers' ever-growing demands. Such a party "will not demand political liberty - it will live underground, under both absolutism and democracy. Its sole demands will be economic demands concerning manual labor. Its sole task will be a conspiracy with the goal of uniting mass workers' strikes into one universal insurrection."1 These professional conspirators would consist, presumably, of Machajski and his followers. But there was no provision in the logic of Makhaevism for such leadership. Machajski chose to ignore the fact that he himself was an intellectual and that his guidance of the workers' movement might be open to the same questions he had voiced in regard to the socialists. ${ }^{2}$ There is at least ground for suspicion that Machajski - once again like Bakunin - was not wholly averse to the notion of taking dictatorial power.

\section{IV}

Since they all shared, to one degree or another, the legacy of Bakunin, the history of the Makhaevists was closely intertwined with that of the anarchists and the SR Maximalists. Makhaevism and anarchism particularly had many points of resemblance. ${ }^{3}$ But it is not correct to

1 Burzhuaznaia revoliutsiia, p. 115.

2 Ivanov-Razumnik, Ob intelligentsii, pp. 135-44. Lozinskii tried to argue that the very fact of having revealed the intelligentsia's true character absolved the Makhaevists from guilt by association and proved their sincere adoption of the proletariat's cause. Chto zhe takoe, nakonets, intelligentsiia (St Pet., 1907), p. 145.

Whether Machajski continued to harbor the notion of a seizure of power remains a moot point. Max Nomad has written that in 1934 Vera Machajska told him quite frankly that she and her husband had been thinking all along in terms of seizing power (Dreamers, Dynamiters, and Demagogues (New York, 1964), pp. 203-04). There is nothing in Machajski's writings, however, to confirm this. In addition, it should be pointed out that his adherents, including as astute an observer as Nomad himself, apparently did not doubt his sincerity.

3 Besides a general similarity of political views, at least some anarchists showed an interest in the same social stratum as the Makhaevists. The anarchist "beznachal'tsy", for instance, declared their intention of working among "the unemployed, vagabonds, migrants", and other outcasts from society. Zagranichnaia gruppa "Beznachalie", "Zaiavlenie", in: Beznachalie (Paris-Geneva), No 1, April, 1905, pp. 1-2. See also Paul Avrich, The Russian Anarchists (Princeton, 1967), pp. 49-54. Iosif Genkin claimed that the beznachal'tsy included former Makhaevists, but this is not confirmed elsewhere (I. Genkin, Po tiur'mam i etapam (St Pet., 1922), pp. 287-88). Genkin's memoirs of his encounters with Makhaevists are often illuminating, but some of his statements regarding Makhaevist groups and the careers of their individual members are based on hearsay and find no corroboration in other sources. 
classify Makhaevism as a variant of anarchism, as is frequently done. Machajski rejected the fundamental, and indeed defining tenet of anarchism, its attitude toward the state. He criticized the anarchists for their direct attack upon the political structure of the state, which, like the Marxists, he believed to be merely a reflection of the economic structure of society. The destruction of the central government and its replacement by local self-governing communes would fail to resolve the question of the management of production, and the workers would find themselves merely carrying out the orders of scientific specialists instead of officials. The anarchist program failed to deal with the problem Machajski considered most fundamental, the problem of the intelligentsia. In the end, he maintained, it would lead to the same result as the Marxist program: a bourgeois revolution which would bring the intelligentsia to power. ${ }^{1}$

The ideological differences between Makhaevism and the SocialistRevolutionaries, even the most staunchly "maximalist" among them, were equally fundamental, to the extent that the social base and source of inspiration of the SR's was the peasantry. Machajski fully shared Marx's views on the "idiocy of rural life". Makhaevism was a thoroughly urban ideology, devoid of respect for the rural virtues or communal principles of the Russian countryside. It was only when the peasant left the land and came to town, either to work in a factory or to demand relief from his distress, that he attracted Machajski's attention. What interested Machajski was the frustration of the uprooted peasant in the city, not the virtues of his previous life in the village.

Nevertheless, Makhaevism did have a good deal in common with its neighbors on the militant fringe. They all rejected the idea that history proceeds in a step-by-step fashion, in accordance with more or less immutable laws. Instead, they believed in the possibility of an immediate "social revolution", meaning a complete and immediate transformation of the existing economic structure and social relationships to be achieved by revolutionary action. Hence they rejected the need for political reform or parliamentary institutions, regarding politics as at best an unnecessary hindrance to the attainment of social ends, and at worst a tool of the propertied classes. And, as a corollary to these two basic tenets, they harbored a distrust of the Marxists (as

1 "An Unfinished Essay", pp. 17-18; Umstvennyi rabochii, Part III, sec. i, pp. 35-53. Despite his borrowing of the anarcho-syndicalist device of the general strike, Machajski saw little value in the work of the anarcho-syndicalists themselves. He criticized them for their adherence to anarchist doctrines, and he expressed the belief that their efforts would lead only to the legalization of trade unions. "An Unfinished Essay", pp. 13-14; Umstvennyi rabochii, Part III, sec. i, p. 49, and sec. ii, p. 5. 
well as other socialists influenced by them), who recognized "scientific laws" of social and historical development and insisted on the establishment of constitutional democracy as the stepping-stone to socialism. These affinities of temperament and general outlook helped to bridge the doctrinal differences that separated the three movements. When it came to actual revolutionary activities the Makhaevists developed close ties with the anarchists and SR Maximalists, and individuals moved freely from the organizations of one party to those of the others.

The first Makhaevist group in Russia originated in Siberia as a product of Machajski's term of exile. In Viliuisk, where he was domiciled, he began to set down his views in writing, and his hectographed essays circulated widely through the exile colonies in the region, winning some converts and evoking a great deal of interest. ${ }^{1}$ On his way back from exile in 1900 Machajski was accidentally arrested upon being mistaken for a recently escaped prisoner, the Social Democrat Iurii Steklov; when copies of his writings were found on him, he was imprisoned. A group of exiles in Irkutsk put up a bond for him which secured his release from jail but prevented him from leaving the city. He now organized a small group of followers and began to agitate among the bakers, typesetters and railroad workers of the city. It was here that he composed the May Day proclamation outlining his plan for a general strike. At the beginning of 1903 the Makhaevists were arrested for organizing a bakers' strike and issuing leaflets calling for an "insurrection of the hungry". Machajski was sentenced to six more years

1 Vera Machajska, "Machajski's Life to 1903", unpublished manuscript in Russian, Max Nomad Archive. A Polish translation of this manuscript is included in Wiera Machajska, "Zycie i poglądy Wacława Machajskiego", in : Wiadomości (London), March 4, 1962. p, 2. The translation, however, omits the names of Machajski's Siberian followers which are given in the original.

The impact Machajski's views made on the exiles was quite remarkable. See, for example, "Listy Jana Strożeckiego do Kazimierza Pietkiewicza", in: Dzieje Najnowsze (Kwartalnik Instytutu Pamięci Narodowej), Vol. I, Part I (Jan.March, 1947), pp. 133-35. Strożecki had been a schoolmate of Machajski and reported reading his pamphlets in Siberia. They also reached Trotsky in his place of exile (L. Trotskii, "Vospominaniia o moei pervoi sibirskoi ssylke", in: Katorga i Ssylka, No 5 (1923), pp. 91-95). An account based on the reminiscences of Machajski's fellow-exiles describes how the exiles of Viliuisk cooperated to reproduce Machajski's first essay: "they recopied it, proof-read it, and forwarded it to all the exile colonies. On many people it made an enormous impression. Not a few exiles became 'Makhaevists' under its influence." G. Lur'e, "Iakutskaia ssylka v devianostye i deviatisotye gody", in: M. A. Braginskii, ed., 100 let iakutskoi ssylki. Sbornik iakutskogo zemliachestva (Moscow, 1934), p. 183. From Siberia, Machajski's views were carried to the rest of the Russian revolutionary movement. Lenin, for instance, learned of them from Trotsky when the two met in London in 1902 (L. Trotskii, Moia zhizn': opyt avtobiografii (Berlin, 1930), I, p. 167). 
of exile in one of the remotest corners of Siberia. Before he could be sent there, however, he escaped from a transfer prison and fled to Western Europe. ${ }^{1}$

Even in his absence, however, the doctrines of Makhaevism spread to European Russia. Odessa seems to have been the first city in which they acquired some influence. The local Social-Democratic committee in Odessa was racked by bitter dissension between the intellectual "committeemen" and the rank-and-file worker members, and this provided fertile ground for the spread of Machajski's anti-intelligentsia views. Iosif Genkin, a Social Democrat, recalled seeing a hectographed copy of L'mstvennyi rabochii in Odessa as early as 1901-02 and conceded that it won some popularity among the unemployed and among workers antagonized by domineering Social-Democratic intellectuals. ${ }^{2}$

In 1903 or 1904 a group calling itself the Irreconcileables arose in Odessa, consisting of both anarchists and Makhaevists, some of the latter being alumni of Machajski's Irkutsk group. ${ }^{3}$ The Irreconcileables displayed their Makhaevist sentiments in their outspoken hostility to the intelligentsia and in their circulation of Umstvennyi rabochii. The police soon put an end to their activities, which appear to have been confined to propaganda work. They were sufficiently well organized, however, for other groups to turn to them for assistance. In January, 1904, a group of Belostok anarchists, hearing that the Irreconcileables were wellendowed with money and literature, sent an emissary to them requesting funds, and he did not return empty-handed.4 After another attempt at joint activity with the anarchists, the Makhaevists formed a group of their own called the Workers' Conspiracy, but it seems to have done little before its collapse except issue a hectographed pamphlet setting forth its views. ${ }^{\mathbf{5}}$

1 On the Irkutsk group see A. Shetlikh, "Pamiati V. K. Makhaiskogo", in: Izvestiia, February 24, 1926, p. 6; Vera Machajska, "Machajski's Life to 1903"; P. A. Garvi, Vospominaniia sotsialdemokrata (New York, 1946), pp. 287-318. ${ }^{2}$ Genkin, Po tiur'mam i etapam, pp. 287-88. On the frictions in the Odessa Social-Democratic committee, see Garvi, Vospominaniia, pp. 107-12, and Allan K. Wildman, The Making of a Workers' Revolution: Russian Social-Democracy, 1891-1903 (Chicago and London, 1967), pp. 110-12.

3 Vera Machajska named two individuals, Bronisław Mitkiewicz and a Chuprina as belonging to both groups. Vera Machajska, "Machajski's Life to 1903", and Letter to Max Nomad, July 25, 1932, Max Nomad Archive. According to Genkin, some SR's were also members, but no other sources mention them ("Sredi preemnikov Bakunina", in: Krasnaia letopis', No 1(22), 1927, p. 190). "Belostochanin, "Iz istorii anarkhicheskogo dvizheniia v Belostoke", in: Al'manakh. Sbornik po istorii anarkhicheskogo dvizheniia v Rossii (Paris, 1909), I, p. 7.

S Vera Machajska to Max Nomad, July 25, 1932; "Ocherk anarkhicheskogo dvizheniia v Odesse”, in: Buntar' (Paris), No 1, December 1, 1906, pp. 30-32; 
One of the members of the Odessa group, Vladimir Lapidus, known as "Striga", exemplifies the streak of fanaticism that marked at least some of those who joined the Makhaevist circles. Born into a comfortable Jewish family, Striga developed into a revolutionary driven by a burning hatred of the bourgeois order and a passionate desire to bring it crashing down. He found it difficult to reconcile himself to the slowmoving strategy of the Social Democrats, particularly their willingness to cooperate with the liberals in order to overthrow the autocracy. The Makhaevist analysis of the class character of the intelligentsia provided him with a satisfying explanation of the Social Democrats' behavior, and in Odessa he joined the Irreconcileables. Makhaevism did not hold him for long, however, and he became an anarchist, for Makhaevism seemed lacking in ideals and a vision of things to come, while Striga by his nature required a cause to which he could devote himself entirely. Indeed, his subsequent fate was much more dramatic than any the Makhaevist program could have offered him: after engaging in terrorist activities in Belostok and Warsaw, he accidentally blew himself up in Paris with one of his own bombs. ${ }^{1}$

Other recruits to Makhaevism were people with experience in the labor movement. One of these was a lady revolutionist named Vera Gurari. Gurari was originally a populist but became a Social Democrat in 1897. In 1899 she organized a workers' circle in Petersburg called the Group for the Self-Emancipation of the Workers. As the name suggests, this group was highly critical of the domination of labor organizations by intellectuals and insisted that the workers must run their own movement. In its views on labor organization and its stress on the primacy of economic over political goals, Gurari's group echoed the sentiments of the Economists, and it distributed the Fconomist

Mikhail Znamenskii, "Tiuremnye vpechatleniia", in Al'manakh, pp. 149-55.

It was no coincidence that Odessa was also one of the main arenas of Zubatovism, a calculated effort by the authorities to exploit the frictions that had developed between the revolutionaries and the workers. Closely parallelling many of Machajski's views - though obviously from an anti-revolutionary perspective Zubatov's agents in Odessa concentrated especially on the accusation that the socialists were preoccupied with political objectives to the neglect, or even the detriment, of the workers' economic interests. See the documents in N. A. Bukhbinder, "Nezavisimaia evreiskaia rabochaia partiia. Po neizdannym arkhivnym dokumentam", in: Krasnaia letopis', No 2-3, 1922, pp. 208-84; and N. A. Bukhbinder, "O zubatovshchine", ibid., No 4, 1922, pp. 289-335.

1 "Tovarishchu i drugu", in: Buntar', No 1, December 1, 1906, pp. 32-34; D. I. Novomirskii, "Anarkhicheskoe dvizhenie v Odesse", in: A. A. Borovoi, ed., Mikhailu Bakuninu, 1876-1926 (Moscow, 1926), p. 248. Other militants, it appears, left Makhaevism for much the same reasons. See Genkin, "Sredi preemnikov Bakunina", p. 191. 
newspaper Rabochaia mysl' to its members. Within a few months the group was arrested and Gurari was exiled to Siberia. ${ }^{1}$

There she met Machajski, became one of his disciples, and participated in his group in Irkutsk. It may have been Gurari who introduced Machajski to Economism, yet another current in the Russian labor movement that voiced criticism of the intelligentsia similar to his own. Of all such currents, this was probably the one closest to Makhaevism, and Rabochaia mysl', which contained some very outspoken antiintelligentsia sentiments, evidently made some impression on him. ${ }^{2} \mathrm{But}$ Economism lacked the kind of revolutionary militancy that animated Machajski, and on the whole he paid little attention to it and does not seem to have considered it a significant departure from the precepts of Social Democracy. After the downfall of the Irkutsk group, Gurari reappeared in Ekaterinoslav in 1903, where, apparently single-handedly, she created a short-lived Makhaevist group. Ekaterinoslav was another town where the Social Democrats were plagued by antagonism between workers and intellectuals, and Gurari recruited several dozen Jewish workers who had formerly belonged to the Social-Democratic organization. ${ }^{3}$ (Gurari herself was a Jew who had converted to Orthodoxy.) After another stay in Siberia she turned up once again as a member of the Makhaevist organization in St Petersburg in 1906 and, according to one account, later became an anarchist. ${ }^{4}$

Another Social Democrat who was drawn to Makhaevism was Moisei Lur'e, a revolutionary who had the distinction of being an authentic worker. Lur'e was a printer by trade and moved around a great deal, circulating revolutionary propaganda and setting up underground organizations. His commitment to revolutionary action and his

1 E. Mikhailova, "Iz kommentariev k 'Chto delat". Gruppa samoosvobozhdeniia rabochego klassa", in: Krasnaia letopis', No 1(12), 1925, pp. 239-48, which includes the group's manifesto, originally published in London in $1899 ;$ N. P. Paialin, Zavod imeni Lenina, 1857-1918 (Moscow-Leningrad, 1933), pp. 78-80. Lenin included this group in his denunciation of Economism in What Is to Be Done? (New York, 1943), pp. 44-45.

'Rabochaia mysl', for instance, voiced the following reservation about studentrevolutionaries: "It must never be forgotten that while they are revolutionaries today, tomorrow they will be procurators, judges, engineers, factory inspectors, in short, the officials of the Russian government" ("Zametki", No 4, October, 1898 , p. 4). Machajski referred to the students as "the future administrators, directors, engineers, judges, procurators" of the proletariat (Umstvennyi rabochii, Part III, sec. i, p. 23).

' V. Levitskii, Za chetvert' veka (Moscow-Leningrad, 1927), Vol. I, Part 2, p. 172. On the relations between workers and intellectuals in the Social-Democratic movement in Ekaterinoslav, see Wildman, Making of a Workers' Revolution, pp. 103-07.

Genkin, Po tiurmam i etapam, pp. 288-90. 
sympathetic attitude to terrorism led some of his associates to consider him more of an anarchist than a Social Democrat. In general he was highly independent in his political views, which were shot through with a feeling of hostility to the intelligentsia. According to one acquaintance Lur'e believed that the intelligentsia had merely "latched on" to the labor movement either to promote the interests of the bourgeoisie or "with its own group interests in mind". ${ }^{1}$ In the mid-nineties, Lur'e and his brother Mikhail organized a group in the south of Russia called the Group of Worker-Revolutionaries. They vehemently opposed the change in tactics of the labor movement from propaganda to agitation, accusing the intelligentsia of withholding "real knowledge" from the workers in order to keep them "a blind instrument". 2

Lur'e was arrested in 1901, and in 1903 he arrived in Iakutsk oblast' to begin serving a term of exile. There, in the region where they had first been disseminated, he encountered the tenets of Makhaevism. Since they sanctioned his distrust of the intelligentsia as well as his revolutionary militancy, it is not surprising that he was strongly attracted to them. Lur'e does not appear to have become an active Makhaevist, but even in 1906, by which time he was organizing military detachments for the Bolsheviks in Petersburg, he was still holding forth enthusiastically about Machajski. ${ }^{3}$

Enough has been said to indicate the constant interaction that occurred between Makhaevism and anarchism. ${ }^{4}$ The chief link between the Makhaevists and the Socialist-Revolutionaries was a man named Evgenii Lozinskii. Lozinskii was a prolific writer on a wide variety of subjects: vegetarianism, education, ethics, and the emancipation of women, to name just a few. In politics, he started off as a SocialistRevolutionary. His articles in SR publications were distinguished by their extremist bent, defending the use of force in the revolutionary

I S. Gel'man and N. Kudrin, "Pamiati Romanovtsa M. V. Lur'e", in: Katorga i Ssylka, No 56, July 1929, p. 155.

2 B. L. Eidel'man, "Imeniny Rossiiskoi Kommunisticheskoi Partii", in: K dvadtsatipiatiletiiu pervogo s"ezda partii (1898-1923) (Moscow-Petrograd, 1923), pp. 35-37.

${ }^{8}$ Gel'man and Kudrin, "Pamiati”, p. 160. At least one member of Lur'e's Group of Worker-Revolutionaries actually did turn up in the Makhaevists' ranks in 1905 (Eidel'man, "Imeniny", p. 37). On Lur'e's Social-Democratic activities, see Wildman, Making of a Workers' Revolution, pp. 192-206.

- Mention should be made of Daniil Novomirskii [Ia. Kirillovskii], an anarchosyndicalist who, while never a Makhaevist, was strongly influenced by Machajski's views on the intelligentsia. See his Iz programmy sindikal'nogo anarkhizma (n. p., 1907); Chto takoe anarkhizm (New York, 1919; first pub. 1907), pp. 57-63; and his newspaper Novyi mir (Paris), No 1, October 15, 1905. See also Avrich, Russian Anarchists, pp. 110-12. Novomirskii, it should be noted, was active in Odessa. 
process and castigating the Marxists for their advocacy of a "bloodless revolution". He outlined a revolutionary program that combined an urban general strike with a mass peasant uprising and terrorist attacks by the revolutionaries. ${ }^{1}$

In 1905, a group of dissidents within the SR party began a campaign to urge the party to adopt a more militant revolutionary position; the ferment begun by this group was ultimately to lead to the formation of the SR Maximalists. The group was sometimes referred to as the "ustinovtsy", after their leader, E. Ustinov - which was one of the pseudonyms of Evgenii Lozinskii. ${ }^{2}$ In the spring and summer of 1905, Lozinskii's group published three issues of a newspaper called Vol'nyi diskussionnyi listok. The paper opposed SR participation in a parliament and any cooperation with liberals; it urged mass revolutionary action rather than efforts to work through political institutions; and it rejected all thought of a "minimum" program, insisting that the party strive not just for the overthrow of autocracy but for the immediate introduction of a socialist order. ${ }^{3}$ Most notable in the views of this group was the prominent role it assigned to the urban workers in the social revolution. Just as Machajski took the June Days of 1848 as his revolutionary model, Vol'nyi diskussionnyi listok drew inspiration from the Paris Commune. Its successor, Kommuna, went even farther in this direction, suggesting that the urban proletariat rather than the peasantry would take the lead in building socialism. ${ }^{4}$

By the end of 1905 Lozinskii's group had been forced out of the SR party and formed an independent organization called the Union of Revolutionary Socialists, under whose imprint Kommuna was published. $^{5}$ Early in 1906, the SR Maximalists, under the leadership of

1 Podolianin [Evgenii Lozinskii], "Nasushchnye voprosy sovremennoi revoliutsionnoi strategii", in: Sbornik statei. Vypusk I (Moscow, 1908; article dated August, 1904), pp. 44-61; " $\mathrm{K}$ voprosu o sile i nasilii v revoliutsionnoi bor'be", ibid. (article dated June, 1904), pp. 19-30.

2 On the "ustinovtsy" see Liudvig Kul'chitskii [Ludwik Kulczycki], Anarkhizm v sovremennom sotsial'no-politicheskom dvizhenii v Rossii (St Pet., 1907), p. 83; and Gorev, "Apoliticheskie i antiparlamentskie gruppy", p. 512. Although both Kulczycki and Gorev pointed out the links between this group and the Makhaevists, neither seems to have been aware that Ustinov was actually Lozinskii. Confirmation of his identity can be found in his writings by following the long trail of pseudonyms he left behind him. See also I. F. Masanov, Slovar' psevdonimov russkikh pisatelei, uchenykh i obshchestvennykh deiatelei (Moscow, 1956-60), III, p. 186.

${ }^{8}$ Vol'nyi diskussionnyi listok (Paris?), No 1, May 1, 1905; No 2, June 10, 1905; No 3, July 5, 1905.

4 "Kak organizovat' revoliutsionnuiu kommunu?", in: Kommuna (Paris?), No 1, December, 1905, pp. 5-7.

5 Ibid., p. 8. 
M. N. Sokolov, began to emerge as a distinct party. Although they too rejected the SR minimum program, the Maximalists appear to have been less anarchistic than the Ustinovites, placing a higher value on state institutions and political freedom. ${ }^{1}$ By 1907, Lozinskii, and possibly some of those who had been associated with him, had broken with the SR's entirely and was espousing Makhaevism. He became the foremost Makhaevist propagandist, and his writings, which were published legally, helped to spread Machajski's views beyond the revolutionary underground to which they had hitherto been confined. ${ }^{2}$ He does not appear to have taken an active part in any Makhaevist organizations, however.

The precise role that Makhaevism played in the evolution of SR Maximalism is difficult to determine, for it is not certain at just what point Lozinskii came under the influence of Machajski's doctrines. His Makhaevist writings date from 1907, but he and the other dissident SR's had ample opportinuty to become acquainted with them earlier. The main center of the SR party abroad was Geneva, and this was also the city where Machajski spent most of his time after 1903 and where, in 1905, he began to publish his writings. (Their publication was financed by a young Russian woman named Janina Berson, the daughter of a St Petersburg banker. She later financed Lozinskii's Makhaevist publications as well. ${ }^{3}$ ) On the other hand, there is no mention of Machajski in Lozinskii's writings before 1907 or in the publications of his group, and they lack the true hallmark of Makhaevism, hostility to the intelligentsia. More probably the main influence on the Ustinov group was anarchism, ${ }^{4}$ but, like others on the militant fringe, some of them

1 E. Tag-in, Otvet Viktoru Chernovu (St Pet., 1906), p. 37n.; Gorev, "Apoliticheskie i antiparlamentskie gruppy", p. 473. For his part, Lozinskii was soon criticizing the Maximalists for their sympathetic attitude to the intelligentsia and the land-owning peasantry. See "Sushchnost' maksimalizma", in: Protiv techeniia (St Pet.), No 2, March 22, 1907, pp. 10-13; and "Maksimalizm i intelligentsiia", ibid., No 3, May 8, 1907, p. 12. Protiv techeniia was a Makhaevist newspaper, three issues of which were published. It was edited by Lozinskii and apparently written entirely by him, for every signed article in it bore his name, his initials, or one of his pseudonyms. To the uninitiated, however, he was able to pass himself off as an entire group.

${ }^{2}$ Lozinskii gave Machajski little credit as the originator of these views, and relations between them were cold. But it was Lozinskii's books that were reviewed in the journals of the day, and it was largely through them that "makhaevshchina" became, if not exactly a household word, at least a familiar Russian political term.

a Nomad, Dreamers, pp. 195-201.

4 This is strongly suggested by the careful efforts the Ustinov group made to differentiate itself from the anarchists. See E. Ustinov, Sovremennyi anarkhizm (Geneva, 1905), p. 2. 
eventually found in Makhaevism the most satisfying rationale for their dissatisfaction with the programs of the socialist parties.

The last active Makhaevist group in Russia arose in St Petersburg in the period of the 1905 revolution. ${ }^{1}$ At the beginning of 1906, Machajski arrived in the capital from abroad and organized a small band of his followers. They set up a clandestine printing press in Finland and began to form propagandist circles in the factories. ${ }^{2}$ But their principal efforts were directed towards the unemployed. Vladimir Voitinskii, at the time a Bolshevik, encountered the Makhaevists frequently as chairman of the Petersburg Council of the Unemployed. In his memoirs he depicted them as wild-eyed desperadoes who urged the hungry to arm themselves with bricks and knives and openly advocated terrorism and "expropriations". At one rally, according to Voitinskii, an offended Mahkaevist drew a pistol on him but quickly backed down when Voitinskii produced a gun of his own. ${ }^{3}$ Several years later, Machajski himself presented quite a different picture of his St Petersburg group's activities. In a letter to his lifelong friend, the Polish novelist Stefan Zeromski, in 1910, he denied categorically that the Petersburg organization had engaged in acts of terrorism or that its members had even carried guns. The group's sole objective, he insisted, had been "a mass strike with economic demands and a demand for the most comprehensive public works for the unemployed"."

Some indication of the actual content of the Makhaevists' propaganda can be found in an anti-Makhaevist resolution adopted by one of the meetings of the unemployed in February, 1907.

"After listening to the representatives of the 'Workers' Conspiracy' with indignation, the meeting rejects their proposals aimed against a democratic republic, the organizations of the working class, and the socialists, and expresses its confidence that only by rallying around the socialist banner can the workers overthrow capitalism and rid themselves of capitalism's inseparable companion, unemployment."5

${ }^{1}$ In 1906 a disciple of Machajski known as Abramek organized a group called "Zmowa Robotnicza" in Warsaw. The group's political commitment seems to have been quite weak, however, and it soon degenerated into little more than a bandit gang (Nomad, Aspects of Revolt, pp. 220-21). Genkin ("Sredi preemnikov Bakunina", p. 190) mentions a Makhaevist group in Vilna but gives no details. 2 Vera Machajska, Letter to Max Nomad, July 25, 1932.

3 V. Voitinskii, Gody pobed i porazhenii (Berlin, 1924), II, pp. 193-96.

"Stanisław Pigoń, "Zygzaki przyjaźni. J. W. Machajski - S. Żeromski", in: Miłe życia drobiazgi (Warsaw, 1964), pp. 385-86.

- Vladimir S. Voitinskii, Peterburgskii sovet bezrabotnykh, 1906-1907 (New York: Russian Institute, Columbia University, 1969), p. 84. According to Voitinskii (p. 83), the anarchists and Maximalists were also active among the unemployed of St Petersburg. 
Other meetings of the unemployed adopted similar resolutions. Throughout 1907, members of the Workers' Conspiracy appeared at political meetings to debate with the SR's and SD's and urge the workers to eject the intelligenty from the labor movement. Here, too, the socialists sponsored resolutions that accused the Makhaevists of abandoning socialism and even suggested that they might be provocateurs. Nevertheless, as late as the fall of 1907 the press was still reporting well-attended workers' meetings called by the Party of the Workers' Conspiracy. ${ }^{1}$ By this time, however, Machajski had been forced to emigrate once again and the movement soon disintegrated. Just how much influence the Makhaevists were able to gain in the capital cannot be determined. But the fact that the socialists found it necessary on a number of occasions to issue denunciations of them suggests, at the very least, that the Makhaevists were widely known among the workers, particularly the unemployed, and that the socialists considered them a force to reckon with.

Both the strengths and weaknesses that Makhaevism as a revolutionary movement displayed were shared to some degree by the rest of the militant fringe. In their search for popular forces whose extremism and depth of alienation matched their own, the Makhaevists focused their attention not on the politically conscious segments of the working class, nor on the landowning peasants with their communal traditions, but on the most disoriented and volatile elements of the population, particularly those concentrated in the towns. They tended, perhaps, to romanticize these elements and to construe all anti-social acts as acts of social protest. But, along with the extreme left as a whole, they perceived more clearly than most of the socialists - with the notable exception of Lenin - the true sources of social upheaval in early twentieth century Russia, caught up in its wrenching transition to an urban industrial society. Consequently, their violent and chaotic image of revolution in Russia proved closer to the truth than that of the more moderate socialists. But Makhaevism, like the rest of the extreme left, was plagued by a chronic weakness of organization and leadership. In addition, although Machajski's criticism of the socialist parties had a strong appeal, his doctrines frequently proved too negative and lacking in visionary content to satisfy the enthusiasts who formed the natural constituency of Makhaevism. Therefore recruits to Makhaevism tended to move on to one of the other militant groups, particularly the anarchists, which offered them a bright vision of the future as well as an

1 "Iz zhizni partii", in : Tovarishch (St Pet.), April 18, 1907, p. 4; June 23, 1907, p. 3 ; August 26, 1907, p. 4; September 11, 1907, p. 2; September 29, 1907, p. 4; October 17, 1907. p. 4. 
active role in the struggle to achieve it. These deficiencies kept Makhaevism, for all its social and psychological insights, a series of tiny, ephemeral sects that rose and fell on the tides of social discontent but were never able to master and control them.

The role of Makhaevism in Russian revolutionary history was not yet over, however. After a brief attempt to resurrect his movement in Russian Poland, ${ }^{1}$ Machajski retired from active politics and concentrated on the problem of making a living in Western Europe. The outbreak of the Russian revolution found him in Paris, working as an archivist in a bank and tutoring. As it did for so many Russian radicals, the revolution rescued him from this humdrum obscurity and gave him a new lease on political life. Ill health delayed him, but by the end of June, 1917, he had quit his bank job and was awaiting a ship provided by the Russian government to take emigrés back to Russia. ${ }^{2}$

Upon his return, a small group of his followers came together and attempted to revive the Workers' Conspiracy in Petrograd. Their chief propagandist among the workers was Bronisław Mitkiewicz, who had earlier belonged to the Makhaevist groups in Irkutsk and Odessa. ${ }^{3}$ Their efforts were unsuccessful, however, and Machajski's principal achievement was the publication of one last expression of his views, a single issue of a journal called Rabochaia revoliutsiia. Here, he repeated his main doctrines in the light of the Bolshevik seizure of power, which presented him with serious problems of interpretation. He had always tended to view Russian Social Democracy as an ideological and political monolith, and he had attached little importance to the trend represented by Lenin and the Bolsheviks. Now he found himself confronted with a revolution, carried out by professed Marxists, that appeared to be considerably more radical than anything he had foreseen. Therefore he could not help preferring the Bolsheviks to either the Whites or the Mensheviks and SR's. ${ }^{4}$ On the whole, however, he felt that the Bol-

1 Nomad, Dreamers, pp. 103-33. Machajski lived in Cracow at this time, under the name Jan Kiżło. Nomad was his most active propagandist.

2 Machajski to Max Nomad, September 28, 1916, and June 29, 1917, Max Nomad Archive. See also Zygmunt Zaremba, Słowo o Wacławie Machajskim (Paris, 1967), pp. 88-95. At the outbreak of the revolution Machajski told friends, "It is not yet my revolution, but it is a revolution, and therefore I'm going to it." (Zaremba, Słowo, p. 95.)

${ }^{3}$ According to Max Nomad, Mitkiewicz ultimately became a Communist and was killed during the Civil War. Zaremba, Slowo, pp. 103-04, 146.

A. Vol'skii, ed., Rabochaia revoliutsiia (Moscow), No 1, June-July, 1918, pp. $1-2,6$. 
sheviks were fulfilling his earlier predictions concerning the outcome of a socialist revolution. The status of the workers had not changed significantly. After the brief experiment with "workers' control" of the factories, the workers were being subjected once again to labor discipline, and their wages were still far below those of the technicians and managers. Like the Jacobins in the French Revolution, the Bolsheviks had effected only political change. They had destroyed the old state but had not introduced true economic equality, and their rule represented not a "dictatorship of the proletariat" but the domination of the intelligentsia - or at least its lower ranks, the "popular intelligentsia". ${ }^{1}$ Machajski called for a universal expropriation of the bourgeoisie, including not only the confiscation of all property and means of production but strict salary limits for the intelligentsia. Only this would create universal equality of incomes and hence equal educational opportunities for the working class. He did not urge the overthrow of the Bolshevik government but reiterated his earlier program of the workers "dictating the laws" to the state. ${ }^{2}$

Despite his criticism of the new regime, Machajski eventually made his peace with it. He took a non-political job as a copy editor for Narodnoe khoziaistvo (later Sotsialisticheskoe khoziaistvo), the journal of the Supreme Council of National Economy. But some of the sentiments that his movement had voiced in the past continued to reverberate in the new Soviet state. Makhaevism had always appealed most to those ardent revolutionaries who feared lest the revolution stop halfway, before it had succeeded in creating the wholly new and better world it promised. In the early twenties, as the wave of revolutionary excitement receded and bureaucratic control began to tighten, this fear revived. After the Tenth Congress of 1921, left-wing discontent within the Communist Party, exacerbated by the introduction of the NEP, was forced underground. It produced two small clandestine organizations, the Workers' Group and the Workers' Truth, which, during their brief existence, expressed their grievances in terms strongly reminiscent of Makhaevism.

The Workers' Group was led by Gabriel Miasnikov, a workerBolshevik who had joined the party in 1906. The keynote of the group's criticism of existing conditions, as contained in its manifesto, was a crude enmity towards middle-class intellectuals. In regard to "bourgeois Kadets, professors and lawyers" the best policy was to "bash their faces in". More unexpected, however, was a similar resentment towards the Bolsheviks. The Soviet government was branded "a high-

1 Ibid., pp. 4-8.

Ibid., pp. 10, 22, 26. 
handed bunch of intelligenty", "a bureaucratic fraternity which holds the country's wealth and government in its hands". With some justification the compiler of the official Soviet account of the Workers' Group labelled it a "hotbed of Makhaevism". 1

The Workers' Truth, on the other hand, was composed of intellectuals rather than workers. It apparently derived its primary inspiration from the ideas of A. A. Bogdanov, but its accusation that a "new class" of exploiters had arisen was very similar to Machajski's. It claimed that the fruits of the revolution had been usurped by a "new bourgeoisie" of intellectuals and party officials. "The working class drags out its miserable existence while a new bourgeoisie (i. e., workers in positions of responsibility, directors of factories, heads of trusts, representatives of Soviet Executive Committees, etc.) and the NEPmen wallow in luxury and call to mind the picture of the life of the bourgeoisie of all eras." Industry was falling under the control of the technical intelligentsia, which "in its methods of work and its ideology ... is bourgeois to the core." The continued exploitation of the workers provided this new bourgeoisie with a high standard of living, while the Communist Party had become "the party of the organizing intelligentsia". ${ }^{2}$

By the end of 1923 the Workers' Group had been silenced by the secret police, and the Workers' Truth soon withered away. ${ }^{3}$ Despite the close similarities of their views to aspects of Makhaevism, there is no evidence linking these opposition groups directly to Machajski or his doctrines. ${ }^{4}$ Machajski was now almost sixty and in poor health, and he professed contentment with the non-political nature of his editorial job. "My work earns me a decent living", he wrote in a letter. "I am satisfied with its 'neutrality', for from the very start I have avoided all ideological guidance of the writing , and my editing is purely technical,

1 V. Sorin, Rabochaia gruppa ("Miasnikovshchina") (Moscow, 1924), pp. 63-64, 109. This book quotes extensively from the manifesto of the Workers' Group and other documents seized by the police.

2"Vozzvanie gruppy 'Rabochaia pravda"', in: Sotsialisticheskii vestnik (Berlin), January 31, 1923, p. 13.

' On the rise and fall of the Workers' Group and the Workers' Truth against the general background of left-wing sentiment within the Communist Party, see Robert Daniels, The Conscience of the Revolution (Cambridge, Mass., 1965), chaps. 7, 9.

4 At the end of 1922, however, Machajski did send Max Nomad, who was now in New York, an urgent request for a copy of his Bankrotstvo sotsializma XIX stoletiia, which apparently he could not locate in Moscow. He even asked Nomad to have a typescript made if he did not have an extra printed copy. Regrettably, he did not explain why he needed it. (Machajski to Max Nomad, December 6, 1922, Max Nomad Archive.) 
purely literary (stylistic corrections, etc.)."1 $\mathrm{He}$ died in Moscow on February 19, 1926.

Makhaevism was not totally forgotten in the Soviet Union, however. At the time of Machajski's death it was still possible to discuss his views openly in Soviet publications. His obituary appeared in both Pravda and Izvestiia, and in the next few years several publications appeared that dealt with Makhaevism, unfavorably but informatively. ${ }^{2}$ Then there was silence until 1938, when Makhaevism again, albeit briefly, became a subject of discussion in the Soviet press. On November 15, 1938, a long statement by the Central Committee of the Communist Party appeared in Pravda. In the midst of it was a reference to "a disparaging attitude towards our intelligentsia", which, the Central Committee complained, had not yet been overcome. Such sentiments were common in pre-revolutionary times, when the intelligentsia mainly served the propertied classes, but were unjustified when applied to the Soviet intelligentsia and dangerous to the state. Therefore, "the TsK VKP(b) considers it necessary to put an end to this 'Makhaevist', anti-Leninist attitude towards the intelligentsia." Three days later, supposedly in response to inquiries from puzzled readers, Pravda ran a special article on Makhaevism itself. ${ }^{3}$

Why did Pravda suddenly draw attention to this almost forgotten movement? The references to Makhaevism were connected with the party's campaign at this time to draw into its ranks the new technicians and specialists trained by the Soviet regime. Just a few months later, at the Eighteenth Congress, this campaign culminated in the abolition of preferential categories for admission to the party, a system which had

1 Machajski to Max Nomad (in Polish), January 29, 1924, Max Nomad Archive. 2 N. N. Baturin, "Pamiati 'makhaevshchiny'!", in: Pravda, March 2, 1926, p. 2; A. Shetlikh, "Pamiati V. K. Makhaiskogo", in: Izvestiia, February 24, 1926, p. 6. Shetlikh had been won over to Machajski's views in Viliuisk. An extract from Umstvennyi rabochii was reprinted in an anthology called Nashi protivniki, ed. by F. Anderson et al. (Moscow, 1928), I, pp. 142-60. L. Syrkin's Makhaevshchina, previously cited, appeared in book form in 1931 after being serialized in Krasnaia letopis', No 6(33), 1929, pp. 184-212, and No 1(34), 1930, pp. 117-45. Lozinskii also had a final word, publishing a little book in which he restated the essential elements of Makhaevism but carefully limited their application to the SocialDemocratic parties of the Second International. He was suspiciously vague in regard to the intelligentsia's position under a "dictatorship of the proletariat". Evgenii Lozinskii, Revoliutsionnaia rol' prava i gosudarstva v epokhu proletarskoi diktatury (Kremenchug, 1928).

s "O postanovke partiinoi propagandy v sviazi s vypuskom 'Kratkogo kursa istorii VKP(b)'", in: Pravda, November 15, 1938, p. 2; "Chto takoe 'makhaevshchina'?", ibid., November 18, 1938, p. 2. 
discriminated against intellectuals. ${ }^{1}$ Denunciations of Makhaevism and its anti-intelligentsia doctrines were part of the effort to prepare the way for this step. Thus it was Makhaevism's ironic fate to be rediscovered and brought before the Soviet public only in order to help raise the status of those "intellectual workers" whom it had always attacked so vigorously.

1 Leonard Schapiro, The Communist Party of the Soviet Union (London, 1960), p. 438. See the speeches by Stalin and Zhdanov at the Eighteenth Congress urging a more positive attitude towards the new Soviet intelligentsia, XVIII s"ezd vsesoiuznoi kommunisticheskoi partii (b), 10-21 marta 1939 g., stenograficheskii otchet (Moscow, 1939), pp. 36-37, 514-17. Stalin's speech is particularly interesting in that it contains almost the same wording as the Pravda article of November 15, 1938, although it omits mention of Makhaevism. 